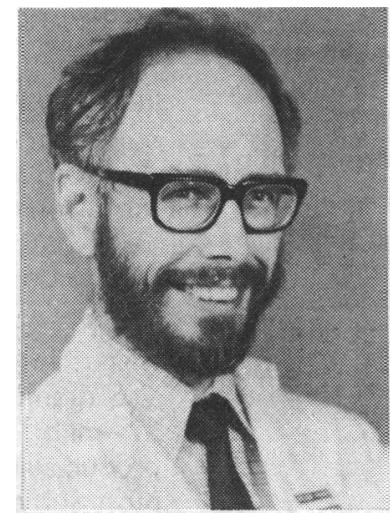

P. Isaacs

\title{
MARATHON WITHOUT A COLON: SALT AND WATER BALANCE IN ENDURANCE RUNNING ILEOSTOMATES
}

P. ISAACS, MD, MRCP

Gastroenterology Unit, Guy's Hospital, London SE1 9RT

\begin{abstract}
Five trained ileostomates completed a marathon in a cool environment without ill effect. During the race, the ileostomy losses of sodium (1.0-2.7 mmol. $\left.\mathrm{h}^{-1}\right)$ and of water $\left(9.2-19 \mathrm{ml}^{-1} \mathrm{~h}^{-1}\right)$ were small, but urinary excretion of sodium was very low $\left(0.2-0.75 \mathrm{mmol} . \mathrm{h}^{-1}\right)$ despite drinking a combination of water and glucose-electrolyte solution. The concentration of potassium in the ileostomy discharge tended to increase, also suggesting a sodium retaining state. Healthy ileostomates after suitable training are successful marathon runners, but the prevalence of mild salt depletion in ileostomates generally suggests that it may be advisable for them to take only glucose-electrolyte solutions when competing at any ambient temperature or when preparing for a marathon which is to take place in a warm environment.
\end{abstract}

\section{INTRODUCTION}

After colectomy and ileostomy for ulcerative colitis, an ileostomate is very likely to return to work and full physical activities (Daly, 1968; Morowitz and Kirsner, 1981; Ritchie, 1971) including a wide range of sports (Daly, 1968; Kennedy et al, 1982). However, many studies have shown that states of mild or borderline salt depletion are very common in these people despite their apparent health (Clarke et al, 1967; Hill et al, 1975; Turnberg et al, 1978; Newton et al, 1982; Haalboom et al, 1983; Kennedy et al, 1983). lleostomates with a large volume of ileostomy discharge are likely to have symptomatic salt and water depletion in warm weather (Gallagher et al, 1962). As endurance running could pose the same risk to ileostomates, this report details fluid and electrolyte balance data in a team of ileostomates competing in the 1983 London Marathon and experience of other ileostomates habitually running long distances.

\section{Present address:}

Dept. of Medicine,

Victoria Hospital,

Blackpool FY3 8NR

\section{METHODS}

\section{Subjects}

Five adult males having had colectomy and ileostomy for ulcerative colitis entered the 1983 London Marathon as a team representing the lleostomy Association of Great Britain (Table I). They and two other ileostomates used to marathon running, completed a questionnaire on their ileostomy function, diet, training programme and experience. None of the subjects had Crohn's disease, none had had additional abdominal surgery (e.g. resection of small intestine, cholecystectomy, gastrectomy).

\section{Method of Study}

Timed collections of urine and ileostomy discharge were made in each subject for 3-4 $h$ before the race and 5-6 $h$ subsequently to include the race period. The subjects were weighed in their running kit on calibrated beam balances, the blood pressure and pulse were taken and a $14 \mathrm{ml}$ venous blood sample withdrawn. This whole procedure was repeated within 5 minutes of finishing the race. One subject refused venepuncture and another was misdirected at the race finish and did not have postrace examination and data are therefore not presented. 
The blood, ileostomy fluid and urine samples were stored at $4^{\circ} \mathrm{C}$ for $24 \mathrm{~h}$. The plasma was analysed by automated multichannel biochemical analysis (M300 Vickers) and automated haematological analyses (Coulter Counter) performed. Glucose concentration was measured in an oxalated plasma sample using a glucose oxidase electrode system (23A glucose analyser, Yellow Springs Instrument Co., Yellow Springs, Ohio). Sodium and potassium were measured in urine and a $1300 \mathrm{~g} \times 15 \mathrm{~min}$ supernate of $50: 50 \mathrm{w} / \mathrm{v}$ dilution of the ileostomy discharge using a flame photometer (IL 33 Instrumentation Laboratories).

\section{Race Conditions}

The marathon was run over a course mainly on the level but with an appreciable drop for the first five miles, in a temperature of $10.2^{\circ} \mathrm{C}$, relative humidity $74 \%$, wind speed 6-8 knots. The weather was cloudy with $7 \mathrm{~mm}$ rainfall before the start of the race. Atmospheric pollutants were:- smoke $20-30 \mu \mathrm{g} \cdot \mathrm{m}^{-3}$ and sulphur dioxide $40 \mu \mathrm{g} \cdot \mathrm{m}^{-3}$.

All runners were offered water or a proprietary glucose electrolyte drink (X-L 1, Collett-Marwell A/S, Asker, Norway) containing glucose $24.9 \mathrm{mmol} .1^{-1}$. fructose $33.0 \mathrm{mmol} . \Gamma^{1}$ sodium chloride $5.6 \mathrm{mmol} . \mathrm{I}^{-1}$ and citrate $7.6 \mathrm{mmol} . \mathrm{I}^{-1}$ if correctly diluted according to the maker's instructions.

\section{RESULTS}

All five ileostomates completed the marathon without ill effect in times of $3 \mathrm{~h} 5 \mathrm{~min}$ to $4 \mathrm{~h} 38 \mathrm{~min}$ (Table I), but observations and specimens were not obtained on subject 5 who unfortunately was misdirected away from the assessment room. Subject 4 refused venepuncture.

\section{Weight Loss}

Weight losses of $1.3 \mathrm{~kg}$ were incurred, the greatest weight loss being in the fastest runner (subject 2, who also drank the least). Urine output (Table II) averaged $37 \mathrm{ml}^{-1}$ before the race (one subject could not produce any urine before the start) and increased in most subjects, two of whom had to urinate during the race. Because in these two the urine collection at the finish is an unknown fraction of the total input in the race, their urinary data are quoted as minimum outputs. Urine sodium concentration and output tended to fall, in one subject (number 5) to an unrecordably low level, despite taking glucose-electrolyte solution in addition to water drinking.

\section{lleostomy Output}

Volume of ileostomy discharge and its sodium concentration showed no uniform change in the group during the race but its potassium concentration tended tof increase in contrast to the relatively unchanged urine

TABLE I

Details of the five male ileostomates running the marathon.

$\begin{array}{cccc}\text { Subject } & \begin{array}{c}\text { Age } \\ \text { (yrs) }\end{array} & \begin{array}{c}\text { Weight } \\ \text { (kg) }\end{array} & \begin{array}{c}\text { lleostomy Age } \\ \text { (years) }\end{array} \\ 1 & 40 & 71.6 & 10 \\ 2 & 42 & 91.0 & 4 \\ 3 & 56 & 73.7 & 13 \\ 4 & 22 & 60.0 & 0.75 \\ 5 & 37 & 68.0 & 2\end{array}$

$\begin{array}{cc}\begin{array}{c}\text { Previous } \\ \text { Full }\end{array} & \begin{array}{c}\text { Harath } \\ \text { Half }\end{array} \\ 1 & 3 \\ 0 & 5 \\ 1 & 3 \\ 0 & 2 \\ 0 & 2\end{array}$

$\begin{gathered}\text { Finish Time } \\ \text { Hours Mins }\end{gathered}$
$\begin{array}{r}4-25 \\ 3-58 \\ 4-38 \\ 3-59 \\ 3-53\end{array}$

Weight Los
in Race (kg)
0.3
3.0
0.9
1.0
1.2

TABLE \|

Details of ileostomy function and urine output in four ileostomates running a marathon during race (R) and pre-race (P).

\begin{tabular}{|c|c|c|c|c|c|c|c|c|c|c|c|c|c|c|c|c|c|c|c|c|c|}
\hline \multirow[b]{3}{*}{ Subject } & \multirow{3}{*}{$\begin{array}{l}\text { Volume } \\
\text { drunk } \\
\text { in race } \\
\mathrm{ml} . \mathrm{h}^{-1}\end{array}$} & \multicolumn{10}{|c|}{ URINE } & \multicolumn{10}{|c|}{ ILEOSTOMY OUTPUT } \\
\hline & & \multicolumn{2}{|c|}{ Volume } & \multicolumn{2}{|c|}{$\begin{array}{l}\text { Sodium } \\
\text { Conc. } \\
\text { mmol. } \Gamma^{-1}\end{array}$} & \multicolumn{2}{|c|}{$\begin{array}{l}\text { Output } \\
\text { mmol. } \mathrm{h}^{-1}\end{array}$} & \multicolumn{2}{|c|}{$\begin{array}{l}\text { Potassium } \\
\text { Conc. } \\
\text { mmol. }\end{array}$} & \multicolumn{2}{|c|}{$\begin{array}{l}\text { Output } \\
\text { mmol.h-1 }\end{array}$} & \multicolumn{2}{|c|}{$\begin{array}{l}\text { Volume } \\
\mathrm{ml} \cdot \mathrm{h}^{-1}\end{array}$} & \multicolumn{2}{|c|}{$\begin{array}{l}\text { Sodium } \\
\text { Conc. } \\
\text { mmol. }\left.\right|^{-1}\end{array}$} & \multicolumn{2}{|c|}{$\begin{array}{l}\text { Output } \\
\text { mmol. } h^{-1}\end{array}$} & \multicolumn{2}{|c|}{$\begin{array}{l}\text { Potassium } \\
\text { Conc. } \\
\text { mmol. } \Gamma^{1}\end{array}$} & \multicolumn{2}{|c|}{$\begin{array}{l}\text { Output } \\
\text { mmol. } h^{-1}\end{array}$} \\
\hline & & $\mathbf{P}$ & $\mathbf{R}$ & $\mathbf{P}$ & $\mathbf{R}$ & $\mathbf{P}$ & $\mathbf{R}$ & $\mathbf{P}$ & $\mathbf{R}$ & $\mathbf{P}$ & $\mathbf{R}$ & $\mathbf{P}$ & $\mathbf{R}$ & $\mathbf{P}$ & $\mathbf{R}$ & $\mathbf{P}$ & $\mathbf{R}$ & $\mathbf{P}$ & $\mathbf{R}$ & $\mathbf{P}$ & $\mathbf{R}$ \\
\hline 1 & 360 & 33 & $>50$ & 84 & 5 & 2.8 & $>.23$ & 64 & 87 & 2.2 & $>4.0$ & 0.5 & 9.5 & - & 115 & - & 1.0 & - & 7.1 & - & 0.1 \\
\hline 2 & 120 & $<5$ & 2 & - & 10 & - & .02 & - & 114 & - & 2.1 & 16 & 19 & 29 & 153 & 0.5 & 2.7 & 3.4 & 10.8 & 0.1 & 1.1 \\
\hline 3 & 100 & 54 & 20 & 78 & 42 & 4.3 & 0.75 & 54 & 104 & 3.0 & 1.9 & 3.0 & 12 & 118 & 144 & 0.3 & 1.7 & 11.1 & 16.6 & 6.03 & 0.2 \\
\hline 4 & 150 & 4.8 & $>40$ & 97 & 0 & 4.5 & 0 & 123 & 119 & 5.7 & $>4.8$ & 21 & 9.2 & 120 & 205 & 2.5 & 1.8 & 11.2 & 19.2 & 0.23 & 0.17 \\
\hline
\end{tabular}


potassium concentrations. Total losses of water (9.5$19 \mathrm{ml}^{-\mathrm{h}^{-1}}$, sodium 1-2.7 $\mathrm{mmol}^{-1} \mathrm{~h}^{-1}$ and potassium $\left(7.19 \mathrm{mmol} . \mathrm{h}^{-1}\right)$ during the race were small.

\section{Plasma Biochemistry}

Changes in plasma biochemical parameters are shown in Table III with reference values found in a group of $\mathbf{9 0}$ normal (colon-intact) competitors in another marathon run in a cool environment (Whiting et al, 1984). The ostomates tended to have lower plasma sodium, higher urea and total protein than the normal marathon runners. Their plasma albumin levels were within the range for normal marathon runners, which was a little higher than for the reference normal for our laboratory. After the race, increases in blood urea, urate and bilirubin occurred in all subjects and these were all most pronounced in subject 2 who ran fast and lost the most weight.

Other parameters, notably plasma $\mathrm{Na}$ and glucose concentrations were unaffected. There was no significant change in haematocrit or platelet count and the neutrophil leucocytosis incurred was within the range expected for a marathon run (Maughan, 1983).

\section{DISCUSSION}

A wide range of sporting activities are undertaken by ileostomates (Kennedy et al, 1982) who are encouraged by their medical advisers to lead a full life. Running is an ideal sport for the ileostomate as it allows sustained aerobic exercise and competition without physical contact. Endurance running may increase the risk of salt depletion in ileostomates, who have lower total body sodium and water than colon-intact normal subjects (Turnberg et al, 1978; Clarke et al, 1967). After a period of adaptation (Leveen et al, 1962) to ileostomy there is a flow from the stoma of about $8 \mathrm{ml} \cdot \mathrm{h}^{-1}$ under fasted, resting conditions (Ladas et al, 1983) and a sodium loss in the ileostomy ejecta of about $70 \mathrm{mmol}$ day $^{-1}$ which continues unchanged when sodium intake is reduced (Kramer, 1966) in comparison with normal faecal sodium losses of about $5 \mathrm{mmol} \mathrm{day}^{-1}$. lleostomates tend to take more salt than the remainder of the population (Bingham et al, 1982) but have small urine volumes and lower urinary sodium excretion (McNeil et al, 1982).

The group of ostomates in this study conform with this general picture, having low urine $\mathrm{Na}$ output, but were able to run a marathon, usually regarded as an achievement of the extremely fit. However, the data contain suggestions that the mild salt depletion has become more pronounced during the run, despite environmental conditions which would probably allow completion of a marathon with less than $100 \mathrm{mmol} \mathrm{Na}$ loss in sweat (Costill, 1972).

A large comparison group of normal subjecis were not studied in this race but comparison with the data of Whiting et al (1984) from the 1982 Aberdeen Marathon, suggests that the ileostomates ran under some dehydration stress. The increase in plasma urate seen in subject 3 for example, is similar to those seen in subjects undertaking exercise without adequate fluid replacement (Somerville et al, 1980). This subject, who on the evidence of pre-race urine output, was the most dehydrated of the group, ran the fastest race and probably drank the least of the group. He consequently finished the race with the greatest weight loss $(3 \mathrm{~kg})$. Subject 1 however may have overdone the rehydration and had a large diuresis $\left(>50 \mathrm{ml}^{-1}\right)$ but still only excreted $0.2 \mathrm{mmol}^{\mathrm{Na} \mathrm{h}} \mathrm{h}^{-1}$.

Increasing dietary sodium intake may simply increase the loss of sodium and water via the stoma (Kramer, 1966) but consumption of glucose-electrolyte solutions by normal ileostomates over a four week period, increase their urinary Na excretion (Newton et al, 1982) and the use of glycose polymer-electrolyte solutions is successful

TABLE III

Start (S) and finish (F) plasma biochemistry in three ileostomates completing a marathon.

\begin{tabular}{|c|c|c|c|c|c|c|c|c|c|c|c|c|c|c|c|c|c|c|c|c|c|c|c|c|c|}
\hline \multirow{3}{*}{\multicolumn{2}{|c|}{$\begin{array}{l}\text { Plasma } \\
\text { Concentration } \\
\text { Normal range } \\
\text { for general } \\
\text { population }\end{array}$}} & \multirow{2}{*}{\multicolumn{2}{|c|}{$\begin{array}{l}\mathrm{Na} \\
\mathrm{mmol} . \mathrm{r}^{-1} \\
135-50\end{array}$}} & \multirow{2}{*}{\multicolumn{2}{|c|}{$\begin{array}{l}\text { Urea } \\
\text { mmol. } \Gamma^{-1} \\
2.5-8.0\end{array}$}} & \multicolumn{2}{|c|}{$\begin{array}{l}\text { Creatine } \\
\text { mmol. } \Gamma^{1}\end{array}$} & \multicolumn{2}{|c|}{$\begin{array}{l}\text { Urate } \\
\text { mmol. } \Gamma^{1}\end{array}$} & \multicolumn{2}{|c|}{$\begin{array}{l}\text { Colcium } \\
\mathrm{mmol} . \Gamma^{-1}\end{array}$} & \multicolumn{2}{|c|}{$\begin{array}{l}\text { Phosphate } \\
\text { mmol. } .^{-1}\end{array}$} & \multicolumn{2}{|c|}{$\begin{array}{l}\text { Protein } \\
\text { g. } .^{-1}\end{array}$} & \multicolumn{2}{|c|}{$\begin{array}{l}\text { Albumin } \\
\text { g. } 1^{-1}\end{array}$} & \multicolumn{2}{|c|}{$\begin{array}{l}\text { Bilimubin } \\
\mu \mathrm{mol} . \Gamma^{1}\end{array}$} & \multicolumn{2}{|c|}{$\begin{array}{l}\text { AAT } \\
u . \Gamma^{1}\end{array}$} & \multicolumn{2}{|c|}{$\begin{array}{l}\text { Alk Phos } \\
\text { u. } .^{-1}\end{array}$} & \multicolumn{2}{|c|}{$\begin{array}{l}\text { Glucose } \\
\text { mmol. } \Gamma^{-1}\end{array}$} \\
\hline & & & & & & 30. & & $<4.7$ & & $2.1-2$ & & $0.6-1$ & & $62-82$ & & $30-43$ & & $<23$ & & $<43$ & & 20.9 & & $<7$ & \\
\hline & & $\mathbf{S}$ & $\mathbf{F}$ & $\mathbf{S}$ & $F$ & $\mathbf{s}$ & $\mathbf{F}$ & $\mathbf{s}$ & $F$ & $\mathbf{S}$ & $\mathbf{F}$ & $\mathbf{s}$ & $\mathbf{F}$ & $\mathbf{s}$ & $\mathbf{F}$ & $\mathbf{S}$ & $\mathbf{F}$ & $\mathbf{S}$ & $\mathbf{F}$ & $\mathbf{S}$ & $F$ & $\mathbf{S}$ & $\mathbf{F}$ & $\mathbf{S}$ & $F$ \\
\hline \multirow{2}{*}{$\begin{array}{l}\text { Data for } \\
\text { normal male } \\
\text { marathon } \\
\text { runners" }\end{array}$} & Mean & 140 & 146 & 4.7 & 6.3 & 93 & 122 & .36 & .40 & 2.4 & 2.5 & .87 & 1.2 & 67 & 72 & 47 & 51 & 11 & 16 & 26 & 34 & 73 & 87 & 5.3 & 5.5 \\
\hline & SD & 2 & 2 & .9 & 1.1 & 9 & 22 & .06 & .07 & .07 & .12 & .15 & .25 & 2.9 & 8.6 & 1.8 & 2.8 & 5.0 & 6.3 & 12 & 12 & 18 & 20 & 1.0 & 1.5 \\
\hline \multicolumn{26}{|l|}{ Ileostomates } \\
\hline Subject 1 & & 133 & 137 & 4.8 & 7.3 & 42 & 51 & .33 & 3.8 & 2.35 & 2.40 & 1.0 & 1.1 & 81 & 78 & 44 & 43 & 20 & 22 & 31 & 30 & 51 & 56 & 4.0 & 4. \\
\hline Subject 2 & & 135 & 134 & 8.4 & 9.4 & 93 & 120 & .42 & .50 & 2.5 & 2.6 & 1.2 & 1.1 & 83 & 83 & 44 & 46 & 2 & 43 & 53 & 58 & 57 & 52 & 3.5 & 4.0 \\
\hline Subject 3 & & 134 & 133 & 7.0 & 8.1 & 54 & 105 & .30 & .38 & 2.4 & 2.6 & 0.9 & 1.1 & 84 & 81 & 45 & 45 & 13 & 23 & 47 & 58 & 65 & 64 & 4.9 & 3.2 \\
\hline
\end{tabular}


in obtaining positive sodium balance in patients with high volume output jejunostomy or ileostomy (Griffin et al, 1982). For intact-gut subjects undergoing endurance exercise, no great benefit has been shown by drinking glucose-electrolyte solutions rather than drinking water (Costill and Sparks, 1973; White and Ford, 1983; Maughan, 1983), though this may not apply to the ileostomate who already is in borderline sodium and water balance.

Despite these theoretical hazards, one 63 year old ileostomate who completed the questionnaire had successfully completed a marathon in a temperature of $88^{\circ}$ in Florida, whilst taking water and some glucoseelectrolyte drinks. One female ileostomate has run a marathon in $3 \mathrm{~h} 22 \mathrm{~min}$ and takes no electrolyte supplement.

The increased incidence of urolithiasis in ileostomates (Maratka and Nedbal, 1964; Morowitz and Kirsner, 1981; Ritchie, 1971; Bambach et al, 1981) is presumably related to their low urine volume and low sodium and magnesium excretion, and marathon runners also share this risk (Milvy et al, 1981) for the same reasons and also possibly because of an increase in uric acid excretion during exercise (Somerville et al, 1980).

Plasma biochemical changes were otherwise unremarkable in comparison with normal (Whiting et al, 1984). Plasma sodium and albumin tended to be lower and total protein higher than other marathon runners but this may reflect the norm for ileostomates. An increased salt-retaining state is also probably reflected by the high potassium concentration in the ileostomy fluid post-race. Aldosterone and other salt retaining steroids increase potassium concentration in colonic and ileal contents (Kramer and Levitan, 1972) and higher potassium in ileostomy ejecta have been noted (McNeil et al, 1982) in those ileostomates with high plasma aldosterone. These salt-retaining states tend to occur in those subjects with high ileostomy volume output and in individuals who had had a colectomy for Crohn's colitis rather than for ulcerative colitis. It is noteworthy that none of the seven ileostomates on whom data were obtained had had colectomy for Crohn's disease.

What advice should be given to the ileostomate who wishes to undertake marathon running? There would seem to be no need to advise against endurance sports undertaken in a cool climate. Common sense attitudes towards training with a gradual increase in speed and duration of runs as in any other competitor should be advised.

lleostomates in general tend to be a cautious, possibly introverted group (Kennedy et al, 1982) and may therefore be more likely than the average person to follow medical advice. Diet should pose few problems (Gazzard et al, 1978; Thomson et al, 1970). Avoidance of foods recognised as causing an increase in ileostomy fluid output such as onions, mushrooms, pineapple, would clearly be sensible before a race but ileostomates eat less vegetables than the general population (Bingham et al, 1982) anyway as they tend to avoid those foods which cause their ileostomy output to increase.

\section{TABLE IV}

Start (S) and finish (F) haematological data in three ileostomates completing a marathon.

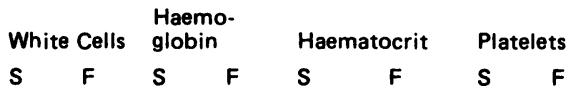

Non-

$\begin{array}{lllllllll}\text { ostomate Mean } & 5.8 & 20.8 & 14.5 & 14.7 & 42.5 & 44.4 & 277 & 364\end{array}$

Marathon

$\begin{array}{llllllllll}\text { Runners* } & \text { SD } & 1.3 & 5.4 & 0.8 & 0.9 & 2.1 & 2.8 & 57 & 70\end{array}$

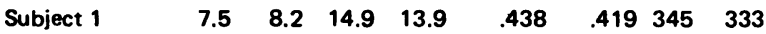

$\begin{array}{lllllllll}\text { Subject } 2 & 4.8 & 16.9 & 16.4 & 16.2 & .492 & .483 & 217 & 264\end{array}$

$\begin{array}{lllllllll}\text { Subject } 3 & 13.5 & 32.6 & 16.1 & 16.0 & .485 & .479 & 311 & 358\end{array}$

* Normal values for non-ileostomate marathon runners from Maughan (1983).

From the current study, a beneficial effect of glucose $\theta$ electrolyte drinks is not proven, but in view of the evidence for borderline sodium depletion in ileostomates in general and the success of glucose-electrolyte drinks in improving their sodium balance (Newton et al, 1982) it would seem reasonable to advise that these should be taken when running in a warm climate or in the training period prior to a run in a warm climate. lleostomates having a large volume of ileostomy discharge, usually those who have had Crohn's colitis or a second operation for obstruction or adhesions, are more likely to be sodium depleted and should therefore be more cautious. lleostomates should be warned against taking large amounts of salt, which may have the effect of increasing the ileostomy dejecta volume (Kramer, 1966) by its osmotic effect.

Management of the stoma during the race or in training caused problems to two of the subjects. The continuous movement is likely to work the appliance loose if it is not carefully applied. One ileostomate was wearing a Seward type bag with a metal buckle which had rubbed the stoma causing some bleeding. Most ileostomates covered the bag with a cloth pouch to obviate skin chafing.

In condusion, it might be said that some features of life with an ileostomy are well suited to marathon running: ileostomates are lighter by $4 \mathrm{~kg}$ than ageand sex-matched controls (McNeil et al, 1982) and at least some of this difference is not due to malnutrition 
but merely the absence of the weight of the colon and its contents. Many non-ostomate runners are troubled with diarnoea (Fogoros, 1980) which typically starts shortly after beginning a run and may be sufficient to interfere with training and require specialist investigation. Nothing is usually found and it seems most likely that this is a variant of irritable bowel syndrome. Most marathon running ileostomates note a decrease in the ileostomy discharge during a race (personal observations by a questionnaire) which suggests that alteration of colonic motility and secretion is the origin of "runner's trots".

\section{ACKNOWLEDGEMENTS}

My thanks to Dr. Dan Tunstall Pedoe for access to the medical facilities in the race, to Dr. Mike Schwar of the Air Pollution Group, Greater London Council and the London Weather Centre for details of atmospheric conditions and to Miss Cathy Weeks for typing the manuscript.

\section{REFERENCES}

Bambach, C. P., Robertson, W. G., Peacock, M. and Hill, G. L., 1981 "Effect of intestinal surgery on the risk of urinary stone formation". Gut 22: 257-263.

Bingham, S., Cummings, J. H. and McNeil, N. I., 1982 "Diet and health of people with an ileostomy. Dietary assessment". Brit.J.Nutr. 47: 399-402.

Clarke, A. M., Chirnside, A., Hill, G. L., Pope, G. and Stewart, M. K., 1967 “Chronic dehydration and sodium depletion in patients with established ileostomies". Lancet 2: 740-743.

Costill, D. L., 1972 "Physiology of marathon running". J.Am.Med.Assoc. 221: 1024-1029.

Costill, D. L. and Sparks, K. E., 1973 "Rapid fluid replacement following thermal dehydration". J.App.Physiol. $34: 299-303$.

Daly, D.W., 1968 "The outcome of surgery for ulcerative colitis". Ann.Roy.Coll.Surg. Engl. 42: 38-57.

Fogoros, D., 1980 "Runners trots: gastrointestinal disturbance in runners”. J.Am.Med.Assoc. 243: $1743-1744$.

Gallagher, N. D., Harrison, D. D. and Skyming, A. P., 1962 "Fluid and electrolyte disturbances in patients with long established ileostomies". Gut 3: 219-223.

Gazzard, B. G., Saunders, B. and Dawson, A. M., 1978 “Diet and stoma function”. Brit.J.Surg. 65: $642-644$.

Griffin, G. E., Fagan, E. F., Hodgson, H. J. and Chadwick, V. S., 1982 "Enteral therapy in the management of massive gut resection complicated by chronic fluid and electrolyte depletion". Dig.Dis.Sci. 27: 902-908.

Haalboom, J. R. E., Poen, H., Struyvenberg, A. and Ten Thije, J. J., 1983 “Life with an ileostomy". Lancet $1: 249$.

Hill, G. L., Goligher, J. C., Smith, A. H. and Mair, W. S. J., 1975 “Long term changes in total body water, total exchangeable sodium and total body potassium before and after ileostomy". Brit.J.Surg. 62: 524-527.

Kennedy, H. J., Lee, E. C. G., Claridge, C. and Truelove, S. C., 1982 "The health of subjects living with a permanent ileostomy". Quart. J.Med. 51 : $341-357$.

Kennedy, H. J., Ali Dujaili, E. A. S., Edwards, R. and Truelove, S. C., 1983 "Water and electrolyte balance in subjects with an ileostomy". Gut 24: 702-705.

Kramer, P., 1966 "The effect of varying sodium loads on the ileal excreta of human ileostomised subjects". J.Clin.Invest. 45: $1710-1718$.

Kramer, P. and Levitan, R., 1972 "Effect of 9-alpha-fluorohydrocotisone on the ileal excreta of ileostomised subjects". Gastroenterology 62: 235-241.

Ladas, S., Isaacs, P. E. T. and Sladen, G. E., 1983 "lleal flow rates in normal subjects and ileostomy output in response to medium- and long-chain triglyceride rich meals". Proceedings of the 7th Hellenic Congress in Gastroenterology, Hellenic Society of Gastroenterology, Athens.

Leveen, H. H., Lyons, A. and Becken, B., 1962 “Physiologic adaptation to ileostomy". Am.J.Surg. 103: 35-41.

McNeil, N. I., Bingham, S., Cole, J. J., Grant, A. M. and Cummings, J. H., 1982 "Diet and health of people with an ileostomy. 2 lleostomy function and nutritional state". Brit.J.Nutr. 47: 407-413.

Maratka, Z. and Nedbal, J., 1964 "Urolithiasis as a complication of the surgical treatment of ulcerative colitis". Gut 5: 214-217.

Maughan, R. J., 1983 "Thermoregulation and fluid balance in marathon competition at low ambient temperature". Int.J.Sports Med. (1985) (In press).

Milvy, P., Colt, E. and Thornton, J., 1981 "A high incidence of urolithiasis in male marathon runners". J.Sports Med.Phys.Fitness 21: 295-298. 
Morowitz, D. A. and Kirsner, J. B., 1981 "lleostomy in ulcerative colitis. A questionnaire study of 1803 patients". Am.J.Surg. 141: 370-373.

Newton, C. R., Drury, P., Gouvers, J. J., Mclntyre, P., Preston, D. M. and Lennard-Jones, J. E., 1982 “Incidence and Treatment of Na depletion in ileostomatists". Scand.J.Gastro. 17: suppl. 74: 159-160.

Ritchie, J. K., 1971 "lleostomy and excisional surgery for chronic inflammatory disease of the colon. A survey of one hospital region. Part II. The health of ileostomists". Gut 12: 536-540.

Somerville, G., Smith, J. R., Toews, C. T., Ward, G. R. and Fox. H. I., 1980 "Purine metabolism during strenuous muscular exercise in man". Metabolism 29: 254-260.

Thomson, T. J., Runcil, J., Khan, A., 1970 "The effect of diet on ileostomy function". Gut 11: 482-485.

Turnberg, L. A., Morris. A. I., Hawker, P. C., Herman, K. J., Shields, R. A. and Horth, C. E., 1978 "Intracellular electrolyte depletion in patients with ileostomies". Gut 19: 563-568.

White, J. and Ford, M. A., 1983 "The hydration and electrolyte maintenance properties of an experimental sports drink". Brit.J.Sports Med. 17: 51-58.

Whiting, P. H., Maughan, R. J., Miller, J. D. B., 1984 "Dehydration and serum biochemical changes in marathon runners". Eur.J.App. Physiol. 52: 183-187.

\section{BOOK REVIEW}

Title: $\quad$ RHEUMATOLOGY - Bailliere's Concise Medical Textbook

Author: David M. Grennen

Publisher: $\quad$ W. B. Saunders, Eastbourne

Price: $\mathbf{f 5 . 9 5}$

This book is written for medical students and MRCP examination candidates. It is well laid out with heavy type headings for each subsection and a reasonable index that makes revising for examination much easier. One of the strengths, for the student, of this little book of 225 pages, is the tables that list differential diagnoses and the diagnostic indices, for this is the way the student gleans many last minute facts, but an index of these would have been helpful.

There is plenty of detail of laboratory tests and their rationale: diagrammatic and photographic illustrations are generally clear but more precise indication to the medical student of what to look for would have been helpful, even when used, some arrows are hard to see. Small facts like the upside down knee X-ray and wrong figure reference (myelography) should easily be corrected in later editions.

Overall a well presented precis that still deals in detail with rheumatic disease including the numerous exotica that appear in this subject. What a shame that manipulation, which in its own right has spawned an industry, should summarily be dismissed and there are one or two treatment modalities that are not even mentioned in this area, but $I$ expect that reflects the needs of examination rather than the requirements of the patients.

At the price it is good value and well recommended.

M. F. T. Read 